\title{
Perilaku Makan Remaja Putri Anemia dan Tidak Anemia di SMA Negeri Kota Kendal
}

\author{
Titi Mursiti* \\ *Magister Promosi Kesehatan FKM Undip \\ E-mail : titimursiti@ymail.com
}

\begin{abstract}
ABSTRAK
Menurut Riset kesehatan Dasar (Riskesdas) tahun 2013 prevalensi anemia pada remaja di Indonesia 20\%. Anemia pada remaja putri salah satunya disebabkan oleh perilaku makan yang kurang baik seperti pembatasan asupan makanan. Tujuan penelitian ini adalah untuk menganalisis faktor yang berhubungan dengan perilaku makan remaja putri anemia dan tidak anemia di SMA Negeri Kota Kendal. Jenis penelitian ini adalah observasional kuantitatif dengan pendekatan cross sectional. Populasi pada penelitian ini adalah semua Siswi SMA Negeri di Kota Kendal. Teknik pengambilan sampel dengan proportionate stratified random sampling pada 91 responden. Hasil penelitian menunjukkan remaja putri yang mengalami anemia sebanyak 25,6\%, Perilaku makan kurang baik sebanyak 44,4\%, pengetahuan kurang baik sebanyak $65,6 \%$. Remaja putri yang sikap terhadap kebutuhan gizinya baik sebanyak $55,6 \%$, yang orang tua berperan sebanyak $58,9 \%$, yang teman sebaya berperan sebanyak $63,3 \%$, dan remaja putri yang media berperan yaitu sebanyak 56,7\%. Perilaku makan remaja putri yang tidak anemia lebih baik daripada perilaku makan remaja putri yang tidak anemia ( $\mathrm{p}$ $=0,035)$. Disimpulkan bahwa perilaku makan remaja putri yang tidak anemia lebih baik daripada perilaku makan remaja putri yang anemia. Sikap remaja terhadap kebutuhan gizi (OR 2,692) dan peran orang tua (OR 3,746) berpengaruh secara bersama - sama terhadap perilaku makan remaja putri.
\end{abstract}

Kata Kunci: perilaku makan, remaja putri, anemia

\section{ABSTRACT}

According to the Health Research (Riskesdas) in 2013 estimated prevalence of anemia in Indonesia $\geq 20 \%$. naemia in adolescent girls one of which is caused by poor eating behaviors such as restriction of food intake, vegetarian diet and others - others. The purpose of this study was to analyze the factors that influence eating behavior of young women anemia and anemia in SMA Kendal. This research is an observational cross-sectional quantitative approach. The population in this study were all high school student Affairs at Kendal Town, sampling technique in this study Using proportionate stratified random sampling in 91 respondents. The results showed the Young Women who are anemic as much as 25.6\%, Behavior eat as much as $44.4 \%$ less good, less good knowledge as much as $65.6 \%$. Young women whose attitude toward good nutritional needs as much as 55.6\%, which parents contribute as much as $58.9 \%$, which peers contribute as much as $63.3 \%$, and the media play a young woman who is as much as $56.7 \%$. Feeding behavior of young women who are not anemic better than eating behavior of young women who are not anemic $(p=0.035)$. Variables that are not associated with feeding behavior is the attitude of young women, the role of parents and the role of peers. This can be concluded that the feeding behavior of young women who are not anemic better than eating behavior of young women are anemic. Attitude ( OR 2.692 ) and the role of parents ( OR 3.746 ) effect together - at the feeding behavior of young women.

Keywords: feeding behavior, young women, anemia 


\section{PENDAHULUAN}

Remaja putri lebih rentan mengalami anemia, karena remaja putri berada pada masa pertumbuhan yang membutuhkan gizi lebih tinggi termasuk zat besi. Remaja putri biasanya memperhatikan bentuk badan, sehingga banyak yang membatasi konsumsi makan dan banyak pantangan makan. Dampak anemia pada remaja sangat besar antara lain dapat mempengaruhi fungsi kognitif, konsentrasi belajar, dan memperlambat daya tangkap pada remaja putri. (Narendra, 2002)

Dampak yang fatal dapat dilihat ketika remaja itu sudah menjadi seorang ibu yang memungkinkan terjadinya kehamilan. Mencegah anemia pada remaja putri sangat penting, karena nantinya wanita yang menderita anemia dan hamil akan menghadapi banyak resiko yaitu: abortus, melahirkan bayi dengan berat lahir rendah, mengalami penyulit lahirnya bayi karena rahim tidak mampu berkontraksi dengan baik ataupun karena tidak mampu meneran, perdarahan setelah persalinan yang sering berakibat kematian.

Angka kematian ibu di Provinsi Jawa Tengah tahun 2012 berdasarkan laporan dari kabupaten atau kota sebesar 116,34 per 100.000 kelahiran hidup, mengalami peningkatan dibandingkan dengan AKI pada tahun 2011 sebesar
116,01 per 100.000 kelahiran hidup. Kematian maternal terjadi pada waktu nifas sebesar 57,93\%, pada waktu hamil sebesar 24,47\% dan pada waktu persalinan sebesar 17,33\% (Dinkes Jateng, 2013). Angka kematian ibu di Kabupaten Kendal sendiri dari tahun ke tahun mengalami kondisi yang fluktuatif, namun yang perlu mendapatkan perhatian adalah kondisi pada tahun sebelumnya (2010) yaitu 150,17 per kelahiran hidup dan mengalami kenaikan pada tahun 2011 sebesar 164,9 per 100.000 kelahiran hidup. Angka tersebut masih sangat jauh dari target yang sudah dicanangkan oleh Provinsi Jawa Tengah untuk Kabupaten Kendal pada tahun 2015 yaitu 90 per 100.000 kelahiran hidup (RAD MDGS Kabupaten Kendal, 2012). Kematian ibu bisa disebabkan karena perdarahan, tekanan darah yang tinggi saat hamil (eklampsi), infeksi, persalinan macet dan komplikasi keguguran Salah satunya perdarahan pada saat persalinan, perdarahan pada saat persalinan bisa disebabkan karena kondisi kesehatan ibu akibat penyakit kronis dan anemia (kurang darah) dan gizi yang buruk.

Dari data di Puskesmas Kendal 2 dan Puskesmas Rowosari 2 pada tahun 2009 dan 2010 ditemukan bahwa dari 640 remaja $25 \%$ nya mengalami anemia dan $75 \%$ nya terjadi pada remaja putri. 


\section{METODE}

Penelitian ini merupakan penelitian kuantitatif dengan pendekatan studi potong lintang (cross sectional). Lokasi penelitian adalah Kabupaten Kendal. Populasi penelitian adalah semua Siswi SMA Negeri di Kota Kendal sejumlah 910 siswi (500 siswi SMA N 1 Kendal dan 410 siswi SMA N 2 Kendal). Sampel penelitian adalah 91 siswi SMA Negeri Kota Kendal. Teknik pengambilan sampel dengan proportionate stratified random sampling (dalam penentuan responden peneliti di bantu oleh guru BK ). Variabel yang diteliti dalam penelitian ini adalah perilaku makan, pengetahuan, sikap, tradisi, pendidikan, sosial ekonomi, pendapatan keluarga, ketersediaan makanan, media, dukungan orang tua, dukungan petugas dan teman sebaya. Penelitian dilakukan selama selama enam hari mulai tanggal 24 februari sampai tanggal 1 maret 2014. Data dikumpulkan dengan metode wawancara kuesioner.

\section{HASIL DAN PEMBAHASAN}

\section{Perilaku Makan remaja putri}

Penelitian ini berfokus pada perilaku makan remaja putri di SMA Negeri di Kota Kendal baik remaja putri yang anemia maupun yang tidak anemia. Perilaku makan ini dibagi menjadi dua kategori yaitu perilaku yang baik dan kurang baik. Hasil penelitian menunjukkan bahwa sebagian besar responden berperilaku baik yaitu sebesar 55,6\%. Untuk perilaku kurang baiknya sebanyak 40 orang atau $44,4 \%$. Perilaku makan yang kurang baik di antaranya adalah bahwa sebagian besar responden $60,0 \%$ mengaku tidak pernah mengkonsumsi suplemen untuk tambah darah. Dalam mengkonsumsi sayuran hijau setiap harinya, hanya $5,6 \%$ responden yang mengakuinya. mengkonsumsi sumber protein hewani minimal 2 kali dalam seminggu hanya $22,2 \%$ responden yang selalu melakukannya.

Responden yang menyatakan selalu mengkonsumsi buah yang mengandung vitamin $\mathrm{C}$ sangat sedikit yaitu $3,3 \%$. Rendahnya kebiasaan mengkonsumsi sayuran hijau di kalangan remaja disebabkan karena gaya hidupnya. Remaja merasa lebih bergengsi dan percaya diri dalam pergaulan ketika mereka mengkonsumsi makanan cepat saji seperti bakso, mie instan dan lainnya. Selain itu, remaja juga sering mengurangi frekuensi makan. Frekuensi makan dapat dilihat dari teratur tidaknya remaja tersebut dalam memenuhi kebutuhan kalorinya sehari-hari. (Beck, 2003)

Perilaku makan remaja putri yang kurang baik akan mengakibatkan anemia. Karena anemia pada umumnya disebabkan oleh kurang gizi terutama 
kekurangan zat besi, vitamin $\mathrm{B} 12$, dan asam folat. kehilangan darah pada saat menstruasi, penyakit kronis, Tuberculosis, cacing usus sehingga menyebabkan penurunan kadar hemoglobin, dan juga aktivitas yang berlebihan yang menyebabkan tubuh kehilangan banyak energi yang di butuhkan. (Dieny, 2009)

\section{Perbedaan perilaku makan remaja putri yang anemia dan tidak anemia}

Penelitian ini menunjukan adanya perbedaan antara perilaku makan remaja putri yang anemia dan tidak anemia. Hal ini tampak jelas dari perbedaan rata-rata nilai skoring pada kedua kelompok remaja putri tersebut. Di mana rata-rata skor pada remaja yang anemia sebesar 17,13. Ini berarti lebih kecil jika dibandingkan ratarata nilai skor perilaku makan remaja putri yang tidak anemia yaitu 18,97. Perbedaan ini sangat jelas ketika nilai $\mathrm{p}$ value pada uji t tersebut sebesar $0,035<0,05$ yang berarti ada perbedaan yang signifikan antara perilaku makan remaja putri yang anemia dan tidak anemia. Remaja putri yang tidak anemia lebih banyak terdapat pada remaja putri yang perilaku makannya baik sebanyak $63,4 \%$ dan yang perilaku makannya kurang baik sebanyak $35,7 \%$.

Perbedaan perilaku makan tersebut menjadi salah satu penyebab kejadian anemia. Pola makan yang salah, yang tidak memenuhi kebutuhan gizi remaja putri dalam hal ini adalah kebutuhan mineral seperti zat besi. Padahal kebutuhan zat besi pada remaja putri lebih besar dari pada kebutuhan zat besi pada anak-anak. Sehingga pola makan remaja putri harus mempertimbangkan kecukupan kebutuhan zat besi yang meningkat.

Perbedaan perilaku makan antara remaja putri yang anemia dan remaja putri yang tidak anemia menunjukkan hubungan yang siginfikan antara perilaku makan dengan kejadian anemia. Di mana remaja putri yang mengalami anemia sebanyak $75 \%$ perilaku makannya kurang baik dan hanya $25 \%$ yang perilaku makannya baik.

Artinya perilaku makan remaja putri kurang baik akan menyebabkan kemungkinan terjadinya anemia. Sehingga hasil penelitian ini sejalan dengan teori bahwa anemia salah satunya disebabkan oleh zat gizi tertentu terutama zat besi, vitamin B12 dan asam folat di mana kekurangan zat gizi tersebut dapat disebabkan oleh perilaku makan remaja putri. Remaja putri yang perilaku makannya baik lebih kecil kemungkinan untuk mengalami anemia dari pada remaja putri yang perilaku makannya kurang baik (misalnya diet vegetarian, mengurangi asupan makanan secara drastis dan sebagainya). 


\section{Faktor-faktor yang berpengaruh}

Berdasarkan uji statistik secara multivariat dengan menggunakan regresi logistik ganda terdapat dua variabel bebas yang berpengaruh secara signifikan terhadap perilaku makan remaja putri dari lima variabel bebas yang ada. Kedua variabel bebas tersebut peneliti tulis secara berurutan sesuai dengan besarnya pengaruh terhadap perilaku makan remaja putri yaitu peran orang tua dalam pemilihan makan sehari-hari dan sikap remaja putri terhadap kebutuhan gizi.

\section{Peran orang tua dalam pemilihan makan sehari-hari}

Hasil uji multivariat dengan menggunakan regresi logistik ganda menunjukkan bahwa variabel peran orang tua dalam pemilihan makan sehari-hari mempunyai $\mathrm{p}$ value paling kecil yaitu 0,005 dengan OR paling besar yaitu 3,746 . Dengan $\mathrm{p}$ value yang sangat kecil dapat diartikan bahwa variabel peran orang tua berpengaruh sangat signifikan terhadap perilaku makan remaja putri. Dengan OR sebesar 3,746 maka remaja putri dengan orang tua yang berperan cenderung berperilaku makan yang lebih baik sebesar 3,746 kali daripada perilaku makan remaja putri dengan orang tua yang tidak berperan jika variabel bebas lainnya dianggap konstan. Ini menunjukkan bahwa peran orang tua dalam pemilihan makan sehari-hari mempunyai pengaruh yang paling dominan terhadap perilaku makan remaja putri dibandingkan variabel lain yang diteliti.

Salah satu faktor yang mempengaruhi perilaku adalah adanya dorongan yang berasal dari lingkungan sekitar yang mampu memperkuat seseorang untuk berbuat atau tidak berbuat sesuatu, mencakup sikap dan perilaku orang tua..

Proses pembentukan dan perubahan perilaku dipengaruhi oleh beberapa faktor yang berasal dari dalam dan luar individu. Faktor dari dalam individu mencakup pengetahuan, kecerdasan, persepsi, sikap, emosi dan motivasi yang berfungsi untuk mengolah rangsangan dari luar. Faktor dari luar individu meliputi lingkungan sekitar, baik fisik maupun non fisik seperti iklim, manusia, sosial, ekonomi, budaya, dan sebagainya. Dari sini dapat dipahami bahwa peran orang tua dalam pemilihan makanan sehari-hari adalah faktor di luar individu remaja putri yang memberikan pengaruh terhadap remaja putri untuk berperilaku makan yang lebih baik. Remaja putri sedikit banyak juga akan mengadopsi kebiasaan makan orang tuanya karena sudah terpola sejak kecil dan juga karena remaja putri masih tinggal bersama orang tua serta secara 
finansial mereka masih sangat bergantung kepada orang tua sehingga remaja putri tidak mempunyai pilihan selain mengikuti kebiasaan makan orang tuanya misalnya dari segi jenis makanan atau frekuensi makannya. (Beck, 1999)

\section{Sikap remaja putri terhadap} kebutuhan gizi

Hasil uji regresi logistik ganda menunjukkan bahwa variabel sikap remaja putri terhadap kebutuhan zat gizi mempunyai $\mathrm{p}$ value sebesar 0,034 yang berarti variabel ini berpengaruh secara signifikan terhadap perilaku makan remaja putri. Selain itu, dengan uji multivariat dengan regresi logistik ganda tersebut dapat diketahui bahwa nilai OR variabel tersebut sebesar 2,6992. Dengan demikian, remaja putri yang mempunyai sikap yang baik terhadap kebutuhan gizi mempunyai kemungkinan untuk berperilaku makan yang lebih baik sebesar 2,692 kali daripada perilaku makan remaja putri yang bersikap kurang baik

Perilaku seseorang terdiri dari tiga bagian penting yaitu kognitif, afektif dan psikomotor. Kognitif dapat diukur dari pengetahuan, afektif dari sikap atau tanggapan dan psikomotor diukur melalui tindakan (praktik) yang dilakukan. Sedangkan Green (1991) menyatakan bahwa sikap seseorang adalah faktor predisposisi untuk memberikan tanggapan terhadap rangsangan lingkungan yang dapat memulai atau membimbing tingkah laku orang tersebut. Lebih jauh lagi ia mengatakan bahwa sikap seseorang berhubungan dengan motivasi individu atau kelompok untuk melakukan sesuatu. (Dieny, 2009)

Dalam banyak penelitian sebagaimana yang dikatakan Robbins, pada umumnya menyimpulkan bahwa individu mencari konsistensi di antara sikap dan perilakunya. Bahkan penelitian baru-baru ini menyimpulkan bahwa sikap memprediksi perilaku masa depan secara signifikan. (Dieny, 2009)

Jadi sikap adalah faktor yang lahir dari dalam individu yang berpengaruh dalam proses pembentukan dan perubahan perilaku. Dalam hal ini, perilaku makan remaja putri yang baik muncul sebagai dorongan dan motivasi dari dalam dirinya yang lahir dari sikap remaja putri yang baik terhadap pemenuhan kebutuhan gizi, begitu juga sebaliknya sikap yang kurang baik akan menjadi salah satu faktor penghalang untuk berperilaku makan yang baik walaupun faktor yang lain mendukung.

\section{Faktor-faktor yang berhubungan}

Hasil perhitungan statistik secara bivariat dengan menggunakan chi square didapatkan beberapa variabel bebas yang terbukti berhubungan secara signifikan 
dengan perilaku makan remaja putri di SMA Negeri di Kota Kendal. Variabelvaraibel bebas tersebut adalah peran orang tua dalam pemilihan makan sehari-hari, sikap remaja putri terhadap kebutuhan gizi, dan peran teman sebaya dalam pemilihan makanan sehari-hari.

Dalam penelitian ini, variabel peran teman sebaya dalam pemilihan makanan sehari-hari dikategorikan menjadi dua, yaitu kategori berperan dan tidak berperan. Hasil penelitian menunjukkan bahwa sebagian besar responden mempunyai teman sebaya yang berperan dalam pemilihan makanan yaitu sebanyak 57 orang $(63,3 \%)$. Sedangkan teman sebaya yang tidak berperan sebesar $36,7 \%$. Meskipun secara umum teman sebaya berperan, akan tetapi masih dijumpai beberapa pernyataan tentang tidak berperannya teman sebaya. Di antaranya adalah walaupun 36,7 \% responden menyatakan selalu mengikuti teman sebaya dalam mengkonsumsi sayuran hijau tetapi ada 2,2 \% yang menyatakan tidak pernah mengikuti teman sebaya dalam mengkonsumsi sayuran hijau, begitu juga dengan konsumsi buah hanya 5,6 \% responden yang menyatakan selalu mengikuti teman sebaya dan 16,7 $\%$ tidak pernah mengikuti teman sebaya dalam mengkonsumsi buah.

Untuk item pernyataan peran teman sebaya dalam mengarahkan pola makan responden $57,8 \%$ mengaku tidak pernah dan $57,8 \%$ mengaku selalu. Untuk peran teman sebaya dalam kebiasaan minum teh $71,1 \%$ menyatakan tidak pernah tetapi ada 2,2 \% responden menyatakan selalu. Untuk peran teman sebaya dalam kebiasaan minum kopi 75,6 \% responden menyatakan tidak pernah tetapi ada 2,2\% responden menyatakan selalu. Peran teman sebaya dalam mengikuti trend tempat jajan yang sedang berkembang $31,1 \%$ responden menyaatakan tidak pernah tetapi ada 2,2\% responden yang menyatakan selalu. Sedangkan untuk peran teman sebaya dalam kebiasaan tidak sarapan pagi di rumah 63,3\% mengaku tidak pernah tetapi ada 2,2 \% yang menyatakan selalu.

Secara bivariat, persentase perilaku makan yang baik lebih banyak terdapat pada remaja putri yang mempunyai teman sebaya yang berperan yaitu sebesar $64,9 \%$ dibandingkan perilaku makan remaja putri yang mempunyai teman sebaya yang tidak berperan yaitu 39,4\%. Sedangkan persentase perilaku makan yang kurang baik lebih banyak terdapat pada remaja putri yang mempunyai teman sebaya yang tidak berperan yaitu 60,6\% dibandingkan perilaku remaja putri yang mempunyai teman sebaya yang berperan yaitu $35,1 \%$. Berdasarkan hasil uji statistik chi square (X2), dengan $\mathrm{CI}=95 \%(\alpha=5 \%)$ 
diperoleh $\mathrm{p}$ value sebesar 0,033 . Hal ini membuktikan bahwa ada hubungan yang signifikan antara peran teman sebaya dalam pemilihan makanan sehari-hari remaja putri dengan perilaku makannya.

Pemilihan makanan pada remaja sering dipengaruhi oleh tekanan social, teman, dan orang tua sebagai panutan yang mempunyai budaya dan keyakinan bahwa tubuh itu harus langsing. (Notoatmodjo, 2007). Hal ini sama dengan apa yang dikatakan Bloom. Menurut Bloom disebutkan bahwa dalam proses pembentukan dan perubahan perilaku dipengaruhi oleh beberapa faktor yang berasal dari dalam dan luar individu. Faktor dari dalm individu mencakup pengetahuan, kecerdasan, persepsi, sikap, emosi dan motivasi yang berpungsi untuk mengolah rangsangan dari luar. Faktor dari luar individu meliputi lingkungan skietar, baik fisik maupun non fisik seperti iklim, manusia, sosial, ekonomi, budaya, dan sebagainya. (Notoatmodjo, 2003). Dari sini dapat dipahami bahwa peran teman sebaya dalam pemilihan makanan sehari-hari adalah faktor luar individu remaja putri yang memberikan pengaruh terhadap remaja putri untuk berperilaku makan. Sedangkan masa remaja, perkembangan emosi dan perilakunya belum stabil. Oleh karena itu masa ini menjadi rawan dan kritis, karena perkembangan tadi menimbulkan kecenderungan ingin bebas, suka mencoba-coba, berkelompok dan mudah terpengaruh. (Ali, 2008)

Hasil penelitian ini sejalan dengan teori bahwa teman sebaya merupakan salah satu faktor yang mempengaruhi perilaku remaja yang dalam hal ini adalah perilaku makan. Walaupun dibeberapa teori mengatakan pengaruh teman sebaya sering berdampak negatif tetapi di hasil penelitian ini menunjukan sebaliknya, yaitu remaja putri yang perilaku makannya baik ternyata lebih banyak terdapat pada remaja putri yang teman sebayanya berperan. Artinya keberadaan teman sebaya pada keadaan tertentu dapat berpengaruh positif bagi perilaku makan remaja putri.

\section{Faktor-faktor yang tidak berhubungan}

Hasil perhitungan statistik secara bivariat dengan menggunakan chi square didapatkan beberapa variabel bebas yang terbukti tidak berhubungan secara signifikan dengan perilaku makan remaja putri di SMA Negeri di Kota Kendal. Variabel-varaibel bebas tersebut adalah pengetahuan tentang kebutuhan gizi, dan peran media dalam pemilihan makanan sehari-hari.

\section{Pengetahuan tentang kebutuhan gizi}

Dalam penelitian ini, variabel pengetahuan dibagi menjadi dua kategori 
yaitu pengetahuan baik dan pengetahuan kurang. Sebagian besar responden mempunyai pengetahuan yang kurang tentang kebutuhan gizi yaitu sebanyak 59 orang $(65,6 \%)$. Sedangkan responden yang berpengetahuan baik hanya 31 orang atau $34.4 \%$. pengetahuan yang kurang adalah $82,2 \%$ responden tidak mengerti sumber zat besi yang paling mudah diserap oleh tubuh, $77,8 \%$ responden tidak memahami kalau daging merah merupakan jenis makanan yang mengandung zat besi dan memiliki nilai biologis tinggi (sehingga mudah diserap tubuh).

Sebanyak 63,5\% responden juga tidak memahami kalau bayam, hati, tempe, daun ketela meruapakan jenis makanan yang paling banyak mengandung zat besi. Hampir sebagian responden (48,9\%) tidak mengerti jenis makanan yang merupakan sumber karbohidrat dan 47,8\% responden juga tidak mengetahui jenis makanan yang mengandung protein. $41,1 \%$ responden tidak memahami kalau vitamin B12 dan C dapat membantu keefektifan pembentukan sel darah merah. Dan 30,0\% responden juga tidak mengetahui kalau air jeruk dapat memaksimalkan penyerapan zat besi dari sayuran hijau (bayam, daun ketela).

Secara bivariat, Berdasarkan hasil uji statistik chi square (X2), dengan $\mathrm{CI}=$ $95 \%(\alpha=5 \%)$ diperoleh $\mathrm{p}$ value sebesar
0,143. Hal ini membuktikan bahwa tidak ada hubungan yang signifikan antara pengetahuan remaja putri tentang kebutuhan gizi dengan perilaku makan remaja putri. Dari sini nampaknya hasil peneltian ini bertentangan dengan teori yang ada, yaitu bahwa pengetahuan merupakan salah satu faktor pemungkin yang dibutuhkan sebelum adanya perilaku sehat yang dalam hal ini adalah perilaku makan yang baik. (Notoatmodjo, 2003). Akan tetapi jika diperhatikan sebenarnya tidak berarti bertentangan dengan teori tersebut. Karena secara persentase, perilaku makan yang baik lebih banyak terdapat pada remaja putri yang berpengetahuan baik yaitu sebesar $67,7 \%$ dibandingkan perilaku makan remaja putri yang berpengetahuan kurang yaitu 49,2\%. Sedangkan persentase perilaku makan yang kurang baik lebih banyak terdapat pada sikap remaja putri yang berpengetahuan kurang yaitu 50,8\% dibandingkan perilaku remaja putri yang berpengetahuan baik yaitu $32,3 \%$. Artinya bahwa remaja putri yang berperilaku yang baik lebih banyak banyak pada mereka yang mempunyai pengetahuan yang baik, demikian juga sebaliknya.

Hasil penelitian ini menunjukkan bahwa tidak setiap orang yang berpengetahun baik akan diikuti oleh perilaku yang baik. Dalam hal ini sesuai dengan apa yang dikatakan oleh Azwar yaitu bahwa tingkat 
pengetahuan seseorang yang tinggi terhadap suatu obyek tidak secara mutlak akan diikuti oleh suatu tindakan yang positif karena tindakan atau perilaku individu dipengaruhi juga oleh banyak faktor lain.

\section{Peran media dalam pemilihan makanan sehari-hari}

Peran media dalam pemilihan makanan pada remaja putri dalam penelitian dapat dikategorisasi menjadi berperan dan tidak berperan. Hasil penelitian ini menunjukkan bahwa sebagian besar media berperan dalam pemenuhan kebutuhan gizi responden yaitu sebanyak 51 orang $(56,7 \%)$. Sedangkan media yang tidak berperan sebesar 43,3\%.

Meskipun sudah menunjukkan bahwa media mempunyai peran, namun beberapa item pernyataan tentang peran media masih terdapat pernyataan bahwa media tidak berperan. Di antaranya adalah pengaruh media terhadap responden dalam pemilihan makanan dan minuman $15,6 \%$ mengaku tidak pernah tetapi ada 3,3\% yang menyatakan selalu, Informasi tentang makanan sehat walaupun 44, $6 \%$ responden menyatakan tidak pernah didapatkan dari media tetapi 3,3\% mengaku selalu menjadikan media sebagai sumber informasi makanan sehat. Informasi makanan sehat dari media hanya $7,8 \%$ yang mengaku tidak pernah dapat diterapkan pada diri mereka dan 1,4
\% mengaku selalu dapat diterapkan. Untuk peran media dalam pola makan vegetarian $40,0 \%$ mengaku tidak pernah tetapi $2,2 \%$ responden mengaku selalu. informasi dari media tentang makanan dapat dipercaya jika ada ahli di dalam iklan tersebut $22,2 \%$ responden mengaku tidak pernah percaya tetapi 5,6\% mengaku selalu percaya. Untuk item pertanyaan apakah media mendorong responden mengurangi jumlah makan $50,0 \%$ responden mengaku tidak pernah tetapi ada $2,2 \%$ yang mengaku selalu mengikuti.

Berdasarkan hasil uji statistik chi square (X2), dengan $\mathrm{CI}=95 \%(\alpha=5 \%)$ diperoleh $\mathrm{p}$ value sebesar 0,175 . Hal ini membuktikan bahwa tidak ada hubungan yang signifikan antara peran media dalam pemilihan makanan sehari-hari remaja putri dengan perilaku makan mereka. Meskipun begitu, persentase perilaku makan yang baik lebih banyak terdapat pada remaja putri dengan media yang berperan yaitu sebesar $62,7 \%$ dibandingkan perilaku makan remaja putri dengan media yang tidak berperan yaitu 46,2\%. Sedangkan persentase perilaku makan yang kurang baik lebih banyak terdapat pada remaja putri dengan media yang tidak berperan yaitu 37,3\%.

Hasil penelitian menunjukan tidak ada hubungan antara media dengan perilaku makan remaja putri, hal ini mungkin 
karena semakin kritisnya remaja dalam menerima informasi dari media, sehingga mereka lebih selektif dalam menerapkan informasi yang didapatkan dari media walaupun informasi dari media sangat gencar dan dikemas dengan sangat menarik.

Penelitian ini ada banyak keterbatasan diantaranya adalah: tidak meneliti variabel pendidikan dan status ekonomi orang tua dari responden padahal variabel tersebut sangat memungkinkan untuk diteliti dan dari beberapa teori menyebutkan bahwa status ekonomi dan pendidikan orang tua merupakan salah satu faktor yang mempengaruhi perilaku makan remaja.

\section{SIMPULAN}

Remaja Putri yang mengalami anemia sebanyak $25,6 \%$ dan yang tidak anemia sebanyak 74,4\%

Perilaku makan remaja putri di SMA Negeri di Kota Kendal yang kurang baik sebanyak $44,4 \%$ dan baik yang sebanyak $55,6 \%$

Sebagian besar responden $(65,6$ $\%)$ mempunyai pengetahuan yang kurang baik tentang kebutuhan gizi terutama pemahaman tentang sumber zat besi yang mudah diserap oleh tubuh $(82,2 \%)$ dan jenis makanan yang banyak mengandung zat besi $(63,3 \%)$

Sikap responden terhadap kebutuhan gizi sebagian besar baik
$(55,6 \%)$ dan yang kurang baik $(44,4 \%)$ terutama bersikap setuju minum teh setelah makan $(24,4 \%)$ dan setuju tidak akan mengkonsumsi sumber makanan hewani supaya tidak mengalami anemia $(16,7 \%)$

Sebagian besar responden mempunyai orang tua yang berperan dalam pemenuhan kebutuhan gizi remaja putri yaitu sebanyak 58,9\% dan yang tidak berperan sebanyak $41,1 \%$

Sebagian besar responden mempunyai teman sebaya yang berperan dalam pemilihan makanan yaitu sebanyak $63,3 \%$ dan yang tidak berperan sebanyak $36,7 \%$

Sebagian besar media berperan dalam pemenuhan kebutuhan gizi responden yaitu sebanyak $56,7 \%$ dan yang tidak berperan sebanyak 43,3\%

Perilaku makan remaja putri yang tidak anemia lebih baik dari pada perilaku makan remaja putri yang anemia. ( $\mathrm{p}=$ 0,035)

Variabel yang berhubungan
dengan perilaku makan remaja putri adalah peran orang tua dalam pemilihan makan sehari-hari, sikap remaja putri terhadap kebutuhan gizi, dan peran teman sebaya dalam pemilihan makanan seharihari.

Variabel yang tidak berhubungan dengan perilaku makan remaja putri adalah pengetahuan tentang kebutuhan 
gizi, dan peran media dalam pemilihan makanan sehari-hari.

Variabel yang berpengaruh secara bersama - sama terhadap perilaku makan remaja putri adalah peran orang tua dalam pemilihan makan sehari-hari (OR 3,746) artinya remaja putri yang orang tuanya berperan cenderung berperilaku makan lebih baik sebesar 3, 746 kali dari pada remaja putri yang orang tuanya tidak berperan dan sikap remaja putri terhadap kebutuhan gizi (OR 2,692) artinya remaja putri yang bersikap baik terhadap kebutuhan gizi cenderung berperilaku makan lebih baik sebesar 2,692 kali dari pada remaja putri yang sikapnya kurang baik.

\section{KEPUSTAKAAN}

Ali M. Psikologi Remaja Perkembangan Peserta Didik. Jakarta : Bumi Aksara;2008.

Almatsier, S. Prinsip Dasar Ilmu Gizi. Jakarta : PT. Gramedia Pustaka Utama, 2003.

Bakta, I. M. Pendekatan Terhadap Pasien Anemia. In : Sudoyo. A. W. Eds. Jakarta : Pusat Penerbit Ilmu Penyakit Dalam FKUI ; 2007

Beck, ME. Ilmu Gizi Dan Diet. Jakarta : Yayasan Esensia Medika, 1998

Depkes. Laporan Nasional Riset Kesehatan Dasar. 2013
Depkes RI. Program Penanggulangan Anemia Gizi Pada Wanita Usia Subur. Jakarta : Depatemen Kesehatan RI, 2003.

Departemen kesehatan RI. Prevalensi Anemia di Indonesia; 2006

Depkes. Laporan Nasional Riset Kesehatan Dasar. 2007

Departemen Gizi dan Kesehatan. Gizi dan Kesehatan Masyarakat. Jakarta: Rajawali; 2011.

Departemen kesehatan RI. Modul Kesehatan Reproduksi Remaja. Jakarta: Departemen Kesehatan RI;2002.

Dieny, F. 2009. Citra Tubuh dan Prilaku Tidak Tepat Dalam mencapai Bentuk tubuh Ideal Pada Siswi di Semarang, Thesis Program Studi Magister Gizi Masyarakat Tahun 2009

Farida I. Determinan Kejadian anemia Pada Remaja Putri di Kecamatan Gebong Kabupaten Kudus . Tesis Universitas

Diponegoro

Semarang. 2006

Mansjoer, A. Kapita Selekta Kedokteran. Jakarta : FKUI, 1999.

Notoatmodjo, S. Pendidikan dan Prilaku Kesehatan, Rhieneka Cipta, Jakarta 2003

Notoatmodjo, S. Kesehatan Masyarakat Ilmu dan Seni, Rhieneka Cipta, Jakarta 2007 
Jurnal Promosi Kesehatan Indonesia Vol. 11 / No. 1 / Januari 2016

Proverawati, A. Anemia dan Anemia

Kehamilan. Yogyakarta:Nuha Medika;2011.

Subagio, HW. Beberapa Pemikiran Untuk

Penyempurnaan Program

Penanggulanan Anemia pada
Kehamilan. Semarang 28 Juli 2007

Taber, B. Kedaruratan Obstetri Dan Ginekologi. Jakarta : Penerbit Buku Kedokteran EGC, 1998. 